\title{
P-18
}

\section{Antibacterial Activity of Oligostilbenoid Derivatives from the Stem Bark of Dryobalanops Lanceolata}

\author{
A. Wibowo, N. Ahmat*, A. S. Hamzah and A. L. M. Low \\ Faculty of Applied Sciences, Universiti Teknologi MARA, 40450 Shah Alam, Selangor Darul Ehsan, Malaysia; \\ E-mail:noriz118@salam.uitm.edu.my
}

Oligostilbenoid (oligomers of 3,5,4'-trihydroxystilbene) have drawn much attention due to its structure complexity, diversity and biological activities. The differences in the structures of oligostilbenoids in each family or genera has attracted interests from scientists of various disciplines to investigate its properties such as phytochemical, biogenetic pathway and chemotaxonomic. The oligostilbenoids in Dryobalanops species (Dipterocarpaceae) is unique due to the unusual condensation type displayed in Dipterocarpaceae family as compared to other oligostilbenoids from other families. In this study, eight oligostilbenoid tetramers derivatives, including malaysianol B (1) [1], hopeaphenol (2) [2], stenophyllol A (3) [3], nepalensinol B (4) [4], vaticanol B (5) and C (6) [5], upunaphenol D (7) [6], and flexuosol A (8) [7] have been isolated from D. lanceolata by using combination of vacuum and radial chromatography techniques. Their structures were established on the basis of their spectroscopic evidences and comparison with published data. The antibacterial activity of the isolated compounds was evaluated using resazurin microtitre-plate assay against Gram-positive and Gram-negative bacterial strains. Compounds $\mathbf{7}$ and $\mathbf{8}$ exhibited promising antibacterial property as they inhibited the cell growth of three Gram-positive strains, Staphylococcus epidermidis, S. aureus and S. xylosus with MIC 25/75, 50/100 and 25/75 $\mu \mathrm{M}$, respectively. If compared with compounds 1-6, the presence of free resveratrol in the skeleton of $\mathbf{7}$ and $\mathbf{8}$ showed significance effect to their activity. In addition, the position of isolated free resveratrol unit in $\mathbf{8}$ gave less activity than terminal in $\mathbf{7}$ due to a disruption of the double bond resonance in the free resveratrol.

Keywords: Dipterocarpaceae, Dryobalanops lanceolata, oligostilbenoid, tetramer, malaysianol B, antibacterial.

\section{REFERENCES}

[1] Wibowo A, Ahmat N, Hamzah AS, et al. Malaysianol B, an oligostilbenoid derivative from Dryobalanops lanceolata. Fitoterapia 2012; 83: 1569-75.

[2] Ito J, Niwa M, Oshima Y. A new hydroxystilbene tetramer named isohopeaphenol from Vitis vinifera 'Kyohou'. Heterocycles 1997; 45: 1809-13.

[3] Ohyama M, Tanaka T, Linuma M, Burandt CL. Jr. Chem Pharm Bull 1998; 46: 663-8.

[4] Yamada M. Stilbenoids of Kobresia nepalensis (Cyperaceae) exhibiting DNA topoisomerase II inhibition. Phytochem 2006; 67: $307-13$.

[5] Tanaka T, Ito T, Nakaya K, Iinuma M, Riswan S. Oligostilbenoids in stem bark of Vatica rassak. Phytochem 2000; 54: 63-9.

[6] Ito T, Furusawa M, Tanaka T, et al. Resveratrol derivatives from Upuna borneensis. Chem Pharm Bull 2005; 53: $219-24$.

[7] Li WW, Li BG, Chen YZ. Flexuosol A, a new tetrastilbene from Vitis flexuosa. J Nat Prod 1998; 61: 646-7. 